\title{
On the Nature of Mixed Cultures of Chlorella pyrenoidosa TX 71105 and Various Bacteria
}

\author{
By G. R. VELA* AND CLESTE N. GUERRA \\ United States Air Force School of Aerospace Medicine, \\ Brooks Air Force Base, Texas, U.S.A.
}

(Received 4 August 1965)

\begin{abstract}
SUMMARY
The growth of several selected micro-organisms in rapidly dividing cultures of Chlorella pyrenoidosa Tx 71105 was studied. Bacterial proliferation was a function of algal growth and bacterial growth occurred, at least in part, as a result of the excretion of organic substances into the culture medium by rapidly dividing algae. These substances capable of supporting bacterial oxidation and growth were varied in kind and were utilized selectively by the different bacteria. Only a small fraction of the soil and air bacteria grew in the algal cultures. The majority of soil and air bacteria survived in mixed culture for several days but did not increase in numbers. On the other hand, 6 out of 8 bacteria pathogenic for man died promptly in cultures of Chlorella pyrenoidosa; but Salmonella typhi and $\boldsymbol{S}$. paratyphi grew well for extended periods of time. Fungi capable of producing macrocolonies on potato glucose agar at $\mathrm{pH} 3.5$ did not increase in numbers during 8 days. Yeasts and actinomycetes were not detected by the methods used; bacteriophages were observed with some regularity.
\end{abstract}

\section{INTRODUCTION}

Recent reports proposing the use of microalgae in 'closed ecological systems' suitable for space vehicles have described the inherent advantages of these organisms as gas exchangers, transformers of human wastes, and as food material (Eley \& Myers, 1964; Myers, 1964; Brown, Kennedy \& Tischer, 1964; McDowell \& Leveille, 1964; Krauss, 1962). It is well recognized that the utilization of algae as symbionts with man in a closed space will result not in a two-organism system but rather in a very complex biological universe. Because of the impracticality of maintaining pure cultures of algae for long periods of time, even in the laboratory, it is assumed that algal populations mixed with selected bacteria will be used. In the opinion of the authors, the feasibility of using mass cultures of algae with or without bacterial contaminants is at present precluded by a dearth of knowledge of the effects of microbial contamination on the algal culture systems. The problem of bacterial contamination of algal cultures has been noted (Krauss \& Thomas, 1954; Eley \& Myers, 1964; Ward, Moyer \& Vela, 1964; Blasco, 1965) but, unfortunately, there are few studies which elucidate the ecological and physiological relationships that must exist in cultures of algae and other micro-organisms living together. A search of the literature showed that previous investigations of the microbiology of algal cultures were concerned primarily with population

* Present address : Department of Biology, North Texas State University, Denton, Texas. 
densities and with the gross effects of bacterial contamination on the algal populations. Myers, Phillips, \& Graham (1951) stated that the presence of bacteria had little effect on the growth rates of Chlorella pyrenoidosa. Myers (1957) reported that bacterial and mould contaminants usually have no effect on algae in rapidly growing steady-state cultures. Mayer, Zuir, Shain \& Ginzburg (1964) stated that bacterial contamination of mass cultures (2000 l.) of algae was not a serious complicating factor and apparently had little or no effect on the productivity of the culture. Ward et al. (1964) presented data that indicated that the yield of mass of C. pyrenoidosa TX 71105 in steady-state cultures was substantially decreased as a result of bacterial contamination, while Nakamura (1963) proved that selected bacterial species enhanced the growth of algae in nutritionally deficient cultures. Nakamura postulated that mixed cultures of Chlorella and bacteria form a true symbiotic relationship in nature and that this is also the case in laboratory cultures. To the contrary, Vladimirova (1960) showed that C. pyrenoidosa Pringh. suppressed bacterial growth. Further studies on the bacteriology of algal cultures were clearly indicated. The purpose of the present report is to present data which may help to characterize the relationships that exist in mixed cultures of algae and other micro-organisms and to evaluate the feasibility of using these in closed systems for the support of man.

\section{METHODS}

Organisms. All work was done with the strain of Chlorella pyrenoidosa designated Tx 71105 by Sorokin \& Myers (1953). Bacteria utilized included Bacterium anitratum (BAT), B. anitratum atypical (BAA), Mima polymorpha (MP), and a Gram-negative organism tentatively assigned to the genus Flavobacterium (GNB). Cultures of fourteen other species of bacteria capable of growing in algal cultures were obtained from mass cultures of algae growing in open non-sterile systems. In addition to the above, a collection of soil and air bacteria was made in locales far removed from laboratory algal cultures. All organisms were selected on the basis of colony morphology and were probably all different one from the other and from BAT, BAA, MP and GNB.

Recently isolated pathogenic organisms of proven virulence used in several experiments were: Salmonella typhi, S. paratyphi, Shigella flexneri, S. dysenteriae, Proteus vulgaris, Streptococcus pyogenes, Staphylococcus aureus and Corynebacterium diphtheriae.

Cultures and analytical methods. The medium used in all flask culture experiments was Knop's medium (Phillips \& Myers, 1954). It was prepared by adding the following, in order, to $950 \mathrm{ml}$. water: $50 \mathrm{ml}$. solution $\mathrm{I}, 10 \mathrm{ml}$. solution II, $0.05 \mathrm{~g} . \mathrm{FeSO}_{4} \cdot 7 \mathrm{H}_{2} \mathrm{O} ; 10 \mathrm{ml}$. solution III, $2 \cdot 5 \mathrm{~g}$. $\mathrm{KNO}_{3}$, adjusted to $\mathrm{pH} 6.0$ before autoclaving.

Solution I: $25 \cdot 0$ g. $\mathrm{MgSO}_{4} \cdot 7 \mathrm{H}_{2} \mathrm{O}, 20 \cdot 0$ g. $\mathrm{KNO}_{3}, 10 \cdot 0$ g. $\mathrm{KH}_{2} \mathrm{PO}_{4}, 2 \cdot 1 \mathrm{~g} \cdot \mathrm{CaCl}_{2}$, $2 \cdot 85 \mathrm{~g} \cdot \mathrm{H}_{3} \mathrm{BO}_{3}$, and water to $\mathrm{I}$ l.

Solution II: $8 \cdot 82 \mathrm{~g}$. $\mathrm{ZnSO}_{4} \cdot 7 \mathrm{H}_{2} \mathrm{O}, 1 \cdot 44 \mathrm{~g} . \mathrm{MnCl}_{2} \cdot 4 \mathrm{H}_{2} \mathrm{O}, 0.924 \mathrm{~g} . \mathrm{H}_{2} \mathrm{MoO}_{4}(85 \%)$, $1.57 \mathrm{~g} \cdot \mathrm{CuSO}_{4} .5 \mathrm{H}_{2} \mathrm{O}, 0 \cdot 49 \mathrm{~g} \cdot \mathrm{Co}\left(\mathrm{NO}_{3}\right)_{2} \cdot 6 \mathrm{H}_{2} \mathrm{O}$, and water to 11 .

Solution III: $50 \mathrm{~g}$. ethylenediamine tetra-acetic acid (EDTA), $31 \mathrm{~g}$. KOH, and water to 11.

The same Knop medium was used in mass culture experiments except that 
$\mathrm{KNO}_{3}$ was replaced by urea in a final concentration of $1.5 \mathrm{~g} . / 1$. (1.1 times equivalent nitrogen). This substitution was made since it is felt that mass cultures of algae in space vehicles would probably use urine urea as nitrogen source.

Small flask cultures were grown in an incubator shaker fitted with fluorescent lights. The gaseous atmosphere of the incubator was maintained at $2 \%(\mathrm{v} / \mathrm{v}) \mathrm{CO}_{2}$ by introducing a mixture of $\mathrm{CO}_{2}$ and air at the rate of $1 \mathrm{l} . / \mathrm{min}$.; incubation temperature was $37^{\circ}$, shaker excursion $5 \mathrm{~cm}$. and fast enough to cause a 'splash' against the flask side but not a 'spray' up to the stoppers. One-litre Erlenmeyer flasks containing $100 \mathrm{ml}$. medium and capped with beakers were used as culture vessels.

Studies on the nature of microbial populations in mass cultures (32 1.) were done in a photosynthetic gas-exchange culture apparatus of the type described by Ward, Wilks \& Craft (1963). $5 \%(\mathrm{v} / \mathrm{v}) \mathrm{CO}_{2}$ in air was introduced into the culture and the temperature maintained at $39^{\circ}$.

Algal populations in all experiments were monitored by replicate counts with a haemocytometer. Bacterial numbers were estimated by triplicate plate counts on Trypticase Soy agar or, in the case of the pathogenic bacteria, Difco brain heart infusion agar. Yeasts and fungi were enumerated on Difco potato glucose agar (pH 3.5) according to the American Public Health Association Manual on Standard Methods for the Examination of Dairy Products (11th ed. 1960).

Actinomycetes and certain pigmented bacteria were grown in a solution containing the following ingredients $(\mathrm{g} . / \mathrm{l}):. 2 \cdot 0 \mathrm{~g} . \mathrm{NaNO}_{3}, 1 \cdot 0 \mathrm{~g} . \mathrm{K}_{2} \mathrm{HPO}_{4}, 0.5 \mathrm{~g}$. $\mathrm{MgSO}_{4} .7 \mathrm{H}_{2} \mathrm{O}, 0.5 \mathrm{~g} . \mathrm{FeSO}_{4} .5 \mathrm{H}_{2} \mathrm{O}, 20 \mathrm{~g}$. reagent grade agar, and $10 \mathrm{~g}$. glucose added as a sterile $10 \%(\mathrm{w} / \mathrm{v})$ aqueous solution to the sterile basal medium.

Culture filtrates. Soluble algal excretion products were separated from organisms by centrifugation and filtration through $0.45 \mu$ washed (Winneberger, Austin \& Klett, 1963) filter membranes. Further separation was obtained by dialysis and extraction as outlined in Fig. 3. Warburg manometry was used to determine which of the fractions obtained were capable of supporting bacterial oxidation. Substances isolated by extraction with organic solvents were taken to dryness, redissolved in water, and taken to dryness again for three complete cycles in an effort to avoid bacterial oxidation of residual organic solvents. Further analyses of the fractions containing oxidizable substances were done by paper and thinlayer chromatography.

\section{RESULTS}

\section{Flask culture studies}

In previous reports (Ward et al. 1963; Ward et al. 1964) workers at this laboratory had noted that the growth of bacteria in algal cultures closely paralleled algal growth. The data presented in the present report confirm and extend those findings. Small flask cultures of chlorella TX 71105 contaminated with pure cultures of selected bacteria were sampled repeatedly during the algal growth phase and well into the stationary phase. Fig. 1 represents an experiment typical of a large number of studies designed to reveal the kinetics of growth of mixed cultures of chlorella $\mathrm{Tx} 71105$ and various bacteria. It was evident that the bacterial populations increased only while the algal component of the culture was actively dividing. It was also noted that bacterial populations at stationary 
phase of algal growth were always of about the same numerical magnitude as the algal populations. This equilibrium was reported previously by Mayer et al. (1962) in large open culture tanks. Since other investigations (Fogg, 1952) have shown

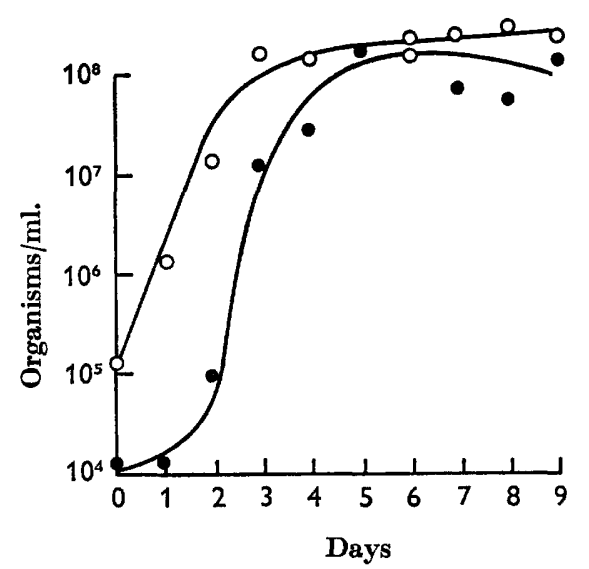

Fig. 1

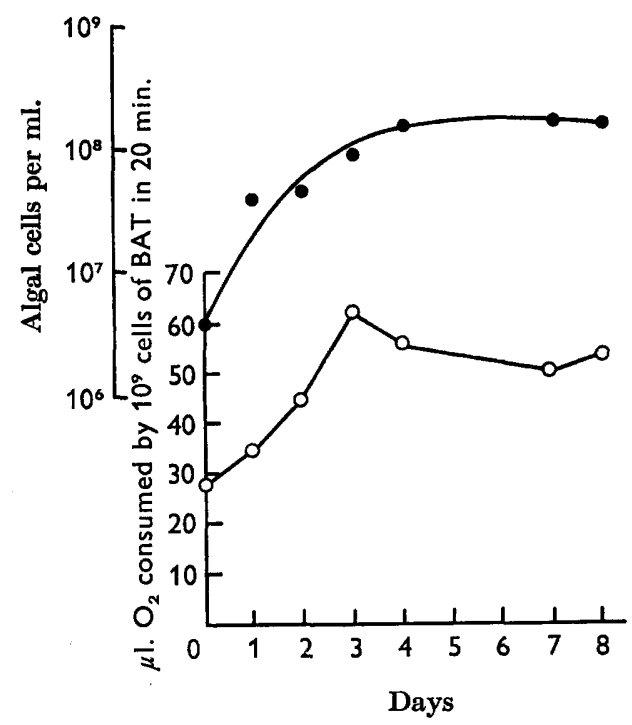

Fig. 2

Fig. 1. Growth curves of Chlorella pyrenoidosa $\mathrm{Tx} 71105$ and the Gram-negative bacterium (GNB) added to the culture as a bacterial contaminant. Algal cells, $O$; viable bacterium GNB,

Fig. 2. Excretion of oxidizable metabolites by axenic Chlorella pyrenoidosa $\mathrm{Tx} 71105$ (lower) as a function of growth (upper). Oxidizable metabolites were measured by classical Warburg manometry.

\section{Table 1. Selective utilization of oxidizable substances} by bacteria growing in algal cultures

\begin{tabular}{|c|c|c|c|c|}
\hline \multirow[b]{3}{*}{$\begin{array}{l}\text { Filtrates from 4-day cultures } \\
\text { of the following: }\end{array}$} & \multicolumn{4}{|c|}{$\begin{array}{c}\text { Ratio of oxygen consumed by these } \\
\text { test bacteria* }\end{array}$} \\
\hline & $\mathbf{B A T} \uparrow$ & $\mathbf{M P} \dagger$ & BAA $\dagger$ & GNB $\dagger$ \\
\hline & & & & \\
\hline Axenic chlorella Tx 71105 & 0 & 0.47 & 0.58 & 0.68 \\
\hline TX $71105+B A T$ & $\mathbf{0}$ & $\mathbf{0}$ & $\mathbf{0}$ & $0 \cdot 16$ \\
\hline $\mathrm{Tx} 71105+\mathrm{MP}$ & $\mathbf{0}$ & $0 \cdot 03$ & $0 \cdot 03$ & $0 \cdot 16$ \\
\hline TX $71105+B A A$ & 0 & $0 \cdot 02$ & $\mathbf{0}$ & $0 \cdot 37$ \\
\hline TX $71105+$ GNB & $0 \cdot 12$ & 0.07 & $0 \cdot 15$ & $\mathbf{0}$ \\
\hline TX $71105+$ all 4 & $\mathbf{0}$ & $\mathbf{0}$ & 0.01 & $\mathbf{0}$ \\
\hline
\end{tabular}

* Ratio of $\mu \mathrm{I} . \mathrm{O}_{2}$ consumed by $10^{9}$ starved bacteria in $20 \mathrm{~min}$. Ratio represents the amount of oxygen utilized by test bacteria using culture filtrate as substrate and $0.025 \mathrm{M}$-glucose as substrate. The results were corrected for endogenous respiration as measured by using Knop's medium i.e.;

$$
\begin{aligned}
& \text { Culture filtrate-Knop's medium } \\
& \text { 0.025 M-glucose-Knop's medium }
\end{aligned}
$$

$\dagger$ BAT, Bacterium anitratum; MP, Mima polymorpha; BAA, Bacterium anitratum atypical; GNB, Gram-negative rod possibly Flavobacterium sp. 
that some algae excrete larger amounts of organic material during active growth periods than they do at resting stages, it was assumed that the same phenomenon occurred in cultures of chlorella $\mathrm{TX} 71105$. To prove that rapidly dividing $\mathrm{TX} 71105$ excreted large amounts of substances capable of supporting bacterial respiration and growth, axenic cultures of the chlorella were sampled daily and assayed for these materials. Figure 2 shows that the excretion of water-soluble substances capable of supporting bacterial respiration was a function of algal growth. These data were confirmed by studies which showed that substances capable of supporting bacterial growth were also excreted in the same fashion. The data (Fig. 2) also indicated that these substances accumulated in the culture fluid and were not removed completely by algal activities or autolytic reactions.

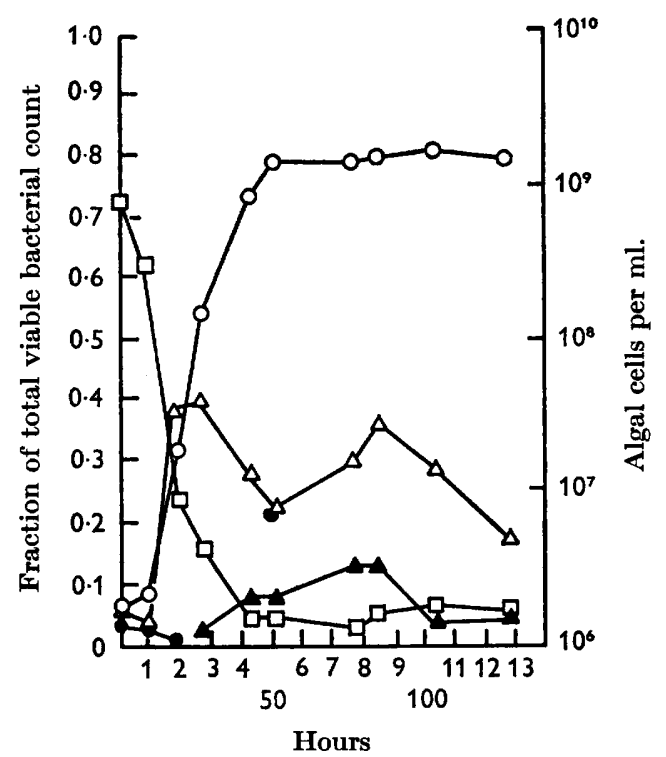

Fig. 3. Shifts in bacterial populations as a function of culture age. Algal cells, $O$; 'white colonies', $\triangle$; 'brown colonies', $\square$; 'green colonies', $\bullet$; and 'red colonies', $\Delta$. Each colony type listed is plotted as a fraction of the total viable bacterial count.

It was then reasoned that if bacteria grew on the excreted metabolites, filtrates from contaminated algal cultures should be free from these metabolites. The data in Table 1 verify this and show that more than one substance was excreted by the chlorella since bacterium GNB could utilize substances not oxidizable by bacteria BAT, BAA and MP.

The products of algal metabolism that can be oxidized by bacteria were dialysable in distilled water when placed in Visking membranes (Union Carbide Corporation, 6733 West 65th Street, Chicago, Illinois). Fractionation of the dialysate (Fig. 4) proved that various classes of chemical compounds capable of supporting bacterial respiration were excreted by chlorella $\mathrm{Tx}$ 71105. The progressive increase in capacity to support respiration of each fraction as purification proceeded cannot be explained at this time. It can, however, be stated that the phenomenon was reproducible. Several experiments have shown that it was not a matter of 
antagonism since mixing of the separated fractions did not result in lowered oxidative capacity of the purer fractions. That is, mixing equal parts of the nondialysable residue and the final extract (or any other combination) gave oxygen uptakes proportional to the quantity of ether-extractable material present, and no inhibition was observed. Also, mixtures of, say, non-dialysable residue and glucose did not result in lowered rates of oxygen consumption by bacteria utilizing the glucose.

Table 2. Growth of bacteria unrelated to algal communities in flask cultures of Chlorella pyrenoidosa $x \times 71105$

\begin{tabular}{|c|c|c|}
\hline \multirow{2}{*}{$\begin{array}{c}\text { Isolate } \\
\text { number }\end{array}$} & \multicolumn{2}{|c|}{ Viable bacteria/ml. } \\
\hline & Day 0 & Day 4 \\
\hline R-PD 1 & $1.1 \times 10^{5}$ & $1.2 \times 10^{4}$ \\
\hline C-Ks 1 & $1.9 \times 10^{6}$ & $<1 \times 10^{3}$ \\
\hline R-BR & $4.5 \times 10^{4}$ & $1.2 \times 10^{4}$ \\
\hline C-sN 2 & $7.7 \times 10^{4}$ & $1.0 \times 10^{8}$ \\
\hline C-AP & $4.7 \times 10^{6}$ & $<1 \times 10^{3}$ \\
\hline R-GR 1 & $1.6 \times 10^{5}$ & $1.0 \times 10^{3}$ \\
\hline C-HD 2 & $5 \cdot 2 \times 10^{5}$ & $1.8 \times 10^{4}$ \\
\hline R-YL & $1.0 \times 10^{6}$ & $6.0 \times 10^{8}$ \\
\hline R-GR4 & $7.8 \times 10^{5}$ & $2.1 \times 10^{4}$ \\
\hline B-RE & $8.8 \times 10^{4}$ & $1.4 \times 10^{4}$ \\
\hline C-sN 1 & $2.4 \times 10^{5}$ & $2.0 \times 10^{3}$ \\
\hline R-GR 2 & $4.4 \times 10^{5}$ & $<1 \times 10^{3}$ \\
\hline R-DD & $2.8 \times 10^{5}$ & $1.0 \times 10^{4}$ \\
\hline C-FA 1 & $4.1 \times 10^{3}$ & $1.2 \times 10^{3}$ \\
\hline C-FA 2 & $4.0 \times 10^{2}$ & $1.9 \times 10^{5}$ \\
\hline C-SP3 & $2.0 \times 10^{2}$ & $3.3 \times 10^{3}$ \\
\hline C-SP 4 & $1.6 \times 10^{3}$ & $2 \cdot 1 \times 10^{4}$ \\
\hline R-PD2 & $1.5 \times 10^{3}$ & $>1 \times 10^{7}$ \\
\hline C-Ks 2 & $4.9 \times 10^{3}$ & $6.0 \times 10^{3}$ \\
\hline R-GR 3 & $6.0 \times 10^{3}$ & $1.0 \times 10^{2}$ \\
\hline C-HDI & $3.1 \times 10^{8}$ & $5.5 \times 10^{3}$ \\
\hline C-SP 2 & $4.0 \times 10^{3}$ & $9.0 \times 10^{2}$ \\
\hline
\end{tabular}

Chromatographic analyses of the two terminal fractions (Fig. 4) revealed the presence of certain organic acids and certain ninhydrin-reactive materials in pure cultures of chlorella TX 71105 that were not found in cultures mixed with bacteria.

It is inferred from these studies that bacteria grow in cultures of chlorella TX 71105 by utilizing substances excreted during the algal growth. It is further inferred that algae/bacterial population equilibria resulted from the establishment of steady-state rates of algal division and cell death at stationary phase. It has been proven that algal metabolites were utilized selectively by different bacteria (Table 1) and that various classes of chemical substances were excreted (Fig. 4).

The literature reviewed implies that algal cultures are subject to bacterial contamination but no reports were found which attempted to describe the nature of the compatible bacteria. Table 2 shows that a few select bacteria could grow well in cultures of chlorella $\mathrm{Tx} 71105$ but that the majority of soil and air bacteria could not proliferate in mixed culture with the algae. It was shown that those organisms incapable of proliferating in algal cultures were also incapable of multiplying in filtrates of axenic cultures or to oxidize these filtrates. Also, when filtrates of axenic cultures of chlorella were inoculated and incubated with bacteria 
incapable of growing in algal cultures and the bacteria subsequently removed, it was plainly evident that the filtrates still contained substances oxidizable by bacteria BAT and GNB. These data indicate that the algae determined the kind of bacteria with which they will grow, according to the nature of the organic substances they excreted.

Table 3 shows that 6 out of 8 bacteria pathogenic for man died out rapidly in cultures of chlorella TX 71105 but that Salmonella typhi and S. paratyphi grew quite well for prolonged periods of time. It is assumed that other human pathogens might also grow in cultures of chlorella $\mathrm{Tx} 71105$.

Table 3. Growth and survival of some pathogens in cultures of Chlorella pyrenoidosa $r \times 71105$

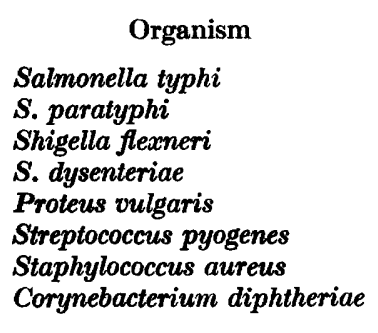

\begin{tabular}{|c|c|c|c|c|c|}
\hline \multicolumn{6}{|c|}{ Days } \\
\hline $\mathbf{0}$ & 1 & $\mathbf{2}$ & 3 & 6 & 7 \\
\hline \multicolumn{6}{|c|}{ Viable organisms/ml. } \\
\hline
\end{tabular}

\begin{tabular}{lcccccc}
\hline $2.0 \times 10^{5}$ & $6.9 \times 10^{6}$ & $4.7 \times 10^{6}$ & $2.9 \times 10^{3}$ & $5.4 \times 10^{4}$ & $3.5 \times 10^{4}$ & $4 \times 11$ \\
$8.9 \times 10^{4}$ & $1.0 \times 10^{6}$ & $8.0 \times 10^{2}$ & $\mathbf{3 . 9} \times 10^{2}$ & $1.8 \times 10^{4}$ & $3.0 \times 10^{2}$ & $7.9 \times 1$ \\
$2.1 \times 10^{5}$ & $8.3 \times 10^{4}$ & $>1<10$ & 0 & - & - & - \\
$2.2 \times 10^{5}$ & $1.0 \times 10^{4}$ & $>1<10$ & 0 & - & - & - \\
$1.5 \times 10^{5}$ & $1.3 \times 10^{6}$ & $9.4 \times 10^{3}$ & $>1<10$ & 0 & - & - \\
$1.7 \times 10^{4}$ & 0 & 0 & - & - & - & - \\
$1.2 \times 10^{5}$ & 0 & 0 & - & - & - & - \\
$1.3 \times 10^{4}$ & 0 & 0 & - & - & - & -
\end{tabular}

\section{Mass culture studies}

Studies of bacterial growth in non-sterilized open mass cultures of chlorella TX 71105 revealed that the same algae/bacteria population relationships existed there as were observed in flask cultures. All mass culture studies utilized the natural microbial flora normally encountered in non-sterilized algal culture systems. It was possible to monitor the growth of heterotrophic and autotrophic bacteria, fungi, yeasts and actinomycetes. Table 4 (representative of the data obtained from 5 experiments) shows that bacteria proliferated as a function of algal growth in mass cultures of chlorella $\mathrm{Tx} 7 \mathbf{7 1 0 5}$. It also shows that heterotrophic bacteria outgrew bacteria capable of utilizing $\mathrm{KNO}_{3}$ as sole nitrogen source. This indicates that most bacterial growth resulted from the utilization of organic nitrogenous substances excreted by the algae rather than from the use of $\mathrm{KNO}_{3}$ from the algal medium. Table 4 presents data which show that the fungi survived but did not grow in cultures of chlorella TX 71105. No significant fungal populations were detected in algal cultures maintained for 8 days and neither yeasts nor actinomycetes were found in these cultures by the methods used.

It was evident that constituents of the detectable microbial populations varied as the algal cultures aged. New cultures generally contained a low but widely varied bacterial population, while ageing cultures in the stationary phase reached equilibrium with a few bacterial species only. Figure 3 shows the shifting population balances as a function of culture age. These population changes were also observed during stationary phase; it is assumed that they were the result of a 


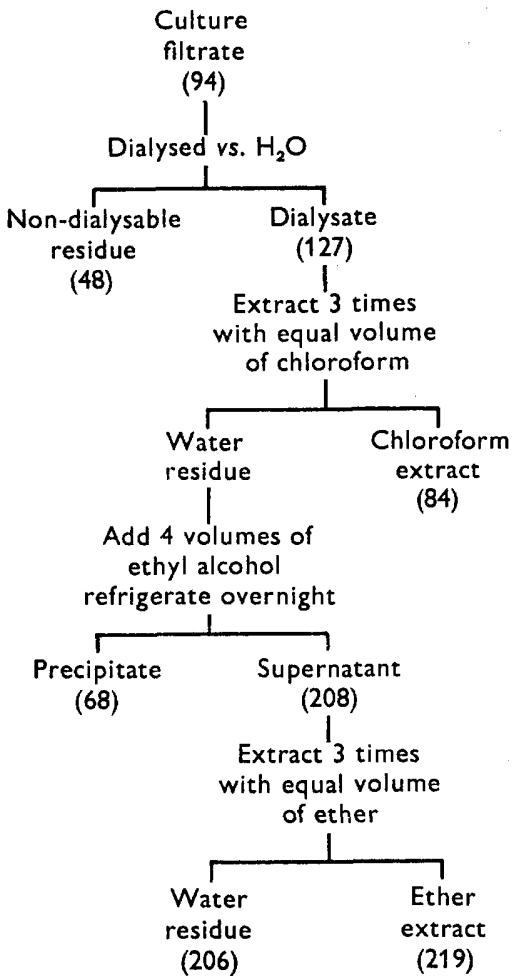

Fig. 4. Fractionation of culture filtrate. Numbers in parentheses give $\mu \mathrm{l} . \mathrm{O}_{2}$ consumed by $10^{9}$ viable Bacterium anitratum in $\mathbf{4 0} \mathrm{min}$. All fractions were reconstituted to original quantity with water.

Table 4. The growth of various micro-organisms in mass cultures of Chlorella pyrenoidosa $\mathrm{Tx} 71105$

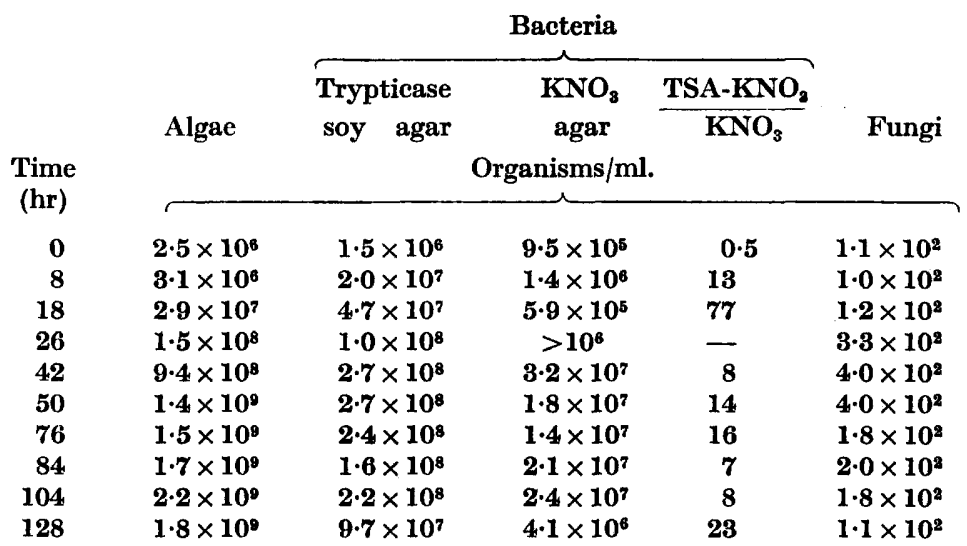

Counts were also made of yeasts and actinomycetes but in no sample did the count of either of these organisms exceed 10 organisms $/ \mathrm{ml}$. 
given organism's ability to utilize substances not available to a faster growing organism.

Throughout these experiments it was obvious that bacteriophages were present in some mass algal cultures. The presence of these phages was confirmed by serial passage on host bacteria isolated from the cultures.

The technical assistance of $\mathrm{Mr} \mathrm{B}$. T. Anderson is gratefully appreciated. We also thank the Bacteriology Section of the U.S.A.F. Epidemiology Laboratory, Lackland AFB, Texas, U.S.A., for providing the pathogenic organisms employed.

The research reported in this paper was funded in part by 'In-House Laboratory Independent Research Funds' U.S.A.F. School of Aerospace Medicine, A.F.S.C., and N.A.S.A. Defense Project no. R-99.

\section{REFERENCES}

BuAsco, R. J. (1965). Nature and role of bacterial contaminants in mass culture of thermophilic Chlorella pyrenoidosa. Appl. Microbiol. 13, 473.

Brown, L. R., Kennedy, M. V. \& Trscher, R. G. (1964). An algal medium produced from human wastes. Devs ind. Microbiol. 5, 245.

Eley, J. H., Jun. \& Myers, J. (1964). Study of a photosynthetic gas exchanger, a quantitative repetition of the Priestley experiment. Texas J. Sci. 16, 296.

FoGg, G. E. (1952). The production of extracellular nitrogenous substances by a bluegreen alga. Proc. Roy. Soc. B, 139, 372.

KraUss, R. W. (1962). Mass culture of algae for food and other organic compounds. Am. J. Bot. 49, 425.

Krauss, R. W. \& Thomas, W. H. (1954). 'The growth and inorganic nutrition of Scenedesmus obliquus in mass culture. Pl. Physiol. 29, 205.

Mayer, A. M., Zuri, U., Shain, Y. \& Ginzburg, H. (1964). Problems of design and ecological considerations in mass culture of algae. Biotech. Bioengin. 6, 173.

Myers, J. (1957). Algal cultures. In Encyclop. Chem. Tech. (1st suppl. vol.) New York: The Interscience Encyclopedia, Inc.

Myers, J. (1964). Use of algae for support of the human in space. In 4th Int. Space Sci. Symp. Warsaw.

Myers, J., Phillips, J. N., Jun. \& Graham, J-R. (1951). On the mass culture of algae. Pl. Physiol. 26, 539.

McDowell, M. E. \& Leveille, G. A. (1964). Algae systems. In National Aeronautics and Space Administration conference on Nutrition in Space and Related Waste Problems. Tampa, Florida.

Nakamura, H. (1963). Studies on the eco-system of Chlorella. Jap. Soc. Pl. Physiol., p. 197. University of Tokyo Press.

Phimlips, J. N., Jun. \& MYers, J. (1954). Measurement of algal growth under controlled steady-state conditions. Pl. Physiol. 29, 148.

Sorokin, C. \& Myers, J. (1953). A high-temperature strain of Chlorella. Science, 117, 330.

Vladimirova, M. G. (1960). Dynamics of the bacterial microflora growth in Chlorella cultures. Translated from Mikrobiologiya, 30, 374 .

Ward, C. H., Moyer, J. E. \& Vela, G. R. (1964). Studies on bacteria associated with Chlorella pyrenoidosa TX 71105 in mass culture. Devs ind. Microbiol. 5, 213.

Ward, C. H., Wilks, S. S. \& Craft, H. L. (1963). Use of algae and other plants in the development of life support systems. Am. Biol. Teach. 25, 512.

Winneberger, J. H., Austin, J. H. \& Kuetr, C. A. (1963). Membrane filter weight determinations. J. Wat. Pollut. Control Fed. 35, 807. 